\title{
Foreseeability IN PATENT LAW
}

\author{
By Matthew J. Conigliaro, Andrew C. Greenberg and Mark A. Lemley
}

\begin{abstract}
In the Festo decision, the Federal Circuit significantly changed the scope of the doctrine of equivalents in patent law. The doctrine of prosecution history estoppel precludes a patent owner from claiming during litigation to own ground given up during patent prosecution. Under the old rule, called the "flexible bar," estoppel was based on a multi-factor test and would apply only if the patentee had no choice but to amend its claims in the way it did. Festo replaced the flexible bar with an "absolute bar," under which virtually any amendment to a patent precludes resort to the doctrine of equivalents for that claim element.

The Supreme Court is now considering whether the flexible or absolute bar is the right rule. We believe there is middle ground in this debate that has been ignored by both parties. Whether prosecution history estoppel applies to any given amendment should depend on the reasonably foreseeable effect of that amendment. Normally, patentees will understand that they are surrendering coverage by amending their patent claims, and so a rule precluding them from reclaiming that ground makes sense. But in some cases the absolute bar will produce unexpected and unintended results. We argue that the application of estoppel should turn on whether the limiting effect of the language with respect to an accused device would have been foreseeable to a reasonable patentee at the time of the amendment. This "foreseeable" bar better balances the competing policies of strong protection for pioneering inventors and notice to improvers who wish to design around a patent.
\end{abstract}

(C) 2001 Matthew J. Conigliaro, Andrew C. Greenberg and Mark A. Lemley.

$\dagger$ Deputy Solicitor General, State of Florida.

$\ddagger$ Principal, Carlton Fields, P.A.

\# Professor of Law, Boalt Hall, University of California at Berkeley; of counsel, Keker \& Van Nest LLP. This article is adapted from an amicus brief filed by two of the authors on behalf of the Institute of Electrical and Electronics Engineers (the "IEEE") in Festo Corp. v. Shoketsu Kinzoku Kogyo Kabushiki Co., 234 F.3d 558 (Fed. Cir. 2000) (en banc), cert. granted, 121 S.Ct. 2519 (U.S. Jun. 18, 2001) (No. 00-1543). However, the IEEE has not participated in the writing of this article and is not responsible for its contents. Similarly, Professor Lemley did not participate in the filing of the brief and is not responsible for its contents. We emphasize that the opinions expressed herein are our own and not necessarily those of our employers or clients. We would like to thank John Clark, Annette James, Douglas McDonald, and Chris Smart for their assistance in the preparation of this article; and Rose Hagan, Lee Hollaar, Peter Menell, and Jay Thomas for comments on an earlier draft. 


\section{TABLE OF CONTENTS}

I. INTRODUCTION .1046

II. SCIENTIFIC PROGRESS IS NOT ADEQUATELY PROMOTED UNDER EITHER THE ABSOLUTE BAR OR FLEXIBLE BAR.

A. Inventors Contribute to Progress through Both Pioneering Inventions and Technological Improvements

B. Patent Law Should Balance its Protective and Notice Functions and Thereby Promote Progress through Both Pioneering Inventions and Technological Improvements

C. Neither the Absolute Bar nor the Flexible Bar Approach to Prosecution History Estoppel Achieves the Appropriate Balance..................................1059

1. Problems with the Flexible Bar .......................................................1060

2. Problems with the Absolute Bar.

III. THE FORESEEABILITY BAR: PROSECUTION HISTORY ESTOPPEL SHOULD BE APPLIED ONLY WHEN THE LIMITING EFFECT OF AN AMENDMENT WITH RESPECT TO AN ACCUSED DEVICE WOULD HAVE BEEN FORESEEABLE AT THE TIME OF THE AMENDMENT .......1064

A. The Foreseeable Bar Rule is Consistent with Patent Policies and Precedent in Other Areas 1065

B. The Foreseeable Bar Rule Overcomes the Failings of the Absolute Bar

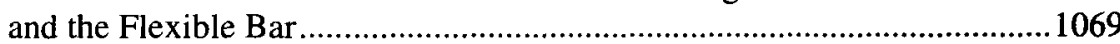

IV. CONCLUSION 1074

\section{INTRODUCTION}

The patent laws are designed to promote the progress of the "useful Arts." Congress sought to achieve this constitutional end by providing both effective protection to inventors and adequate notice to the public. Its goal was to strike an appropriate balance between two competing goals: giving adequate economic incentives to pioneering inventors while ensuring that the improvers who followed-and the public as a whole-could make effective use of inventions. ${ }^{2}$

Both policies are implicated by recent cases involving the doctrine of equivalents in patent law. The scope of a patent is determined by its claims, the written definition of the invention. ${ }^{3}$ But patent law has long permitted patentees to expand the scope of the patent grant beyond the lit-

1. U.S. CONST. art. I $\S 8, \mathrm{cl} .8$.

2. As Lord Mansfield put it in England at the time:

[W] must take care to guard against two extremes equally prejudicial; the one, that men of ability, who have employed their time for the service of the community, may not be deprived of their just merits, and the reward of their ingenuity and labor; the other, that the world may not be deprived of improvements, nor the progress of the arts be retarded.

Sayre v. Moore, 102 Eng. Rep. 139, 140 (1785) (Lord Mansfield, C.J.).

3. Markman v. Westview Instruments, Inc., 517 U.S. 370 (1996). 
eral reach of the patent claims in certain circumstances. Under the doctrine of equivalents, a patent owner may prevent another from making a device that does not literally infringe on the patent, but which differs only insubstantially from the patented invention. Were it otherwise, the Supreme Court explained in Graver Tank, patentees would effectively lose all protection for their inventions because it is often trivial to avoid the literal terms of a patent. ${ }^{4}$ The doctrine of equivalents therefore enhances the strength of a patent by giving the courts the flexibility to expand the patent's scope beyond that of its literal terms.

Such expansion comes at a cost, however. In particular, as the Supreme Court recognized in Warner-Jenkinson, broad application of the doctrine of equivalents threatens to undermine the notice function of patents by preventing the public from being able to determine the scope of a patent ex ante. ${ }^{5}$ In Warner-Jenkinson, the Court restricted the reach of the doctrine of equivalents by applying another judicially created doctrine, prosecution history estoppel. ${ }^{6}$ Prosecution history estoppel prevents patentees from relying on the doctrine of equivalents to broaden their patents in ways that are inconsistent with the amendments or arguments they made to the United States Patent and Trademark Office ("PTO") during patent prosecution. ${ }^{7}$

However, broad application of prosecution history estoppel is costly as well. While prosecution history estoppel is consistent with the notice function, its liberal use threatens to make patent protection ineffective, rendering it a "hollow and useless thing" roadmap to avoiding infringement in nearly every case.

The Federal Circuit has struggled to strike the right balance between the broad protection offered to patentees by application of the doctrine of equivalents and the public's right to notice of the bounds of a patent. To date, the court has not succeeded. Rather, it has oscillated between two different approaches to prosecution history estoppel. Until 2000, the overwhelming majority of Federal Circuit decisions applied a flexible bar that, under certain circumstances, permitted patentees to expand their patents under the doctrine of equivalents notwithstanding the representations

4. Graver Tank \& Mfg. Co. v. Linde Air Prods. Co., 339 U.S. 605, 607 (1950) ("Outright and forthright duplication is a dull and very rare type of infringement. To prohibit no other would place the inventor at the mercy of verbalism and would be subordinating substance to form. It would deprive him of the benefit of his invention ....").

5. Warner-Jenkinson Co. v. Hilton Davis Chem. Co., 520 U.S. 17, 29 (1997).

6. Id at 30-34.

7. Id.

8. Graver Tank, 339 U.S. at 607. 
they made to the PTO during prosecution. ${ }^{9}$ In Festo, however, the Federal Circuit reversed course, deciding en banc that a complete or "absolute bar" should preclude patentees from relying on the doctrine of equivalents as to any claim element that was added or amended during prosecution. ${ }^{10}$ As to those claim elements, only literal infringement is now actionable.

Neither approach defines a workable and just framework for balancing patents' protective and notice functions. The absolute bar improperly treats the notice function as paramount, severely diluting necessary patent protections and disproportionately encouraging minor variations or mere copies over genuine technological improvement and more fundamental, pioneering innovations. The flexible bar, on the other hand, heightens the protective function in a manner that sacrifices much of the notice function, resulting in uncertainty regarding the scope of a patent and thus discouraging incremental innovation through technological improvements. The flexible bar also weakens prosecution history estoppel dramatically. Under neither rule is scientific progress well served.

We believe there is a middle ground in this debate, one thus far ignored by advocates of both the flexible and absolute bars. The Federal Circuit need not have resorted to Festo's absolute bar to cure the deficiencies of the flexible bar. We suggest instead that the Supreme Court use the Festo case now before it to adopt what we call a "foreseeable bar." Under this approach, the doctrine of equivalents should apply, notwithstanding a limiting amendment or argument during a patent's prosecution, unless the limiting effect of the language with respect to an accused device would have been foreseeable to a reasonable patentee at the time of the amendment. Such a rule is supported by case law from the Supreme Court and the Federal Circuit, and presents the best means of effectuating patents' protective and notice functions to promote all forms of progress, including both pioneering inventions and technological improvements.

Unlike the flexible and absolute bars, the foreseeable bar is workable. It would be comprehensible to patent professionals and readily applied and

9. See, e.g., Hughes Aircraft Co. v. United States, 140 F.3d 1470 (Fed. Cir. 1998); Litton Sys., Inc. v. Honeywell, Inc., 140 F.3d 1449 (Fed. Cir. 1998); Modine Mfg. Co. v. U.S. Int'l Trade Comm'n, 75 F.3d 1545 (Fed. Cir. 1996); Dixie USA, Inc. v. Infab Corp., 927 F.2d 584 (Fed. Cir. 1991); Black \& Decker, Inc. v. Hoover Serv. Ctr., 886 F.2d 1285 (Fed. Cir. 1989); Envtl. Instruments, Inc. v. Sutron Corp., 877 F.2d 1561 (Fed. Cir. 1989); LaBounty Mfg., Inc. v. U.S. Int'l Trade Comm'n, 867 F.2d 1572 (Fed. Cir. 1989); Sun Studs, Inc. v. ATA Equip. Leasing, Inc., 872 F.2d 978 (Fed. Cir. 1989); Hughes Aircraft Co. v. United States, 717 F.2d 1351 (Fed. Cir. 1983).

10. Festo Corp. v. Shoketsu Kinzoku Kogyo Kabushiki Co., 234 F.3d 558 (Fed. Cir. 2000) (en banc), cert. granted, 121 S.Ct. 2519 (U.S. Jun. 18, 2001) (No. 00-1543). 
reviewed by the judiciary. The foreseeable bar also avoids the most extreme examples of injustice associated with the flexible and absolute bars. The foreseeable bar best serves the policies underlying the Patent Clause and the Patent Act by most fully promoting progress of the useful arts.

Our discussion is divided into two principal parts. In Part $\Pi$, we discuss the nature of scientific progress, which requires encouraging both pioneering innovations and improvements on existing ideas. We explain why neither the absolute bar of Festo nor the flexible bar that preceded it effectively serves these purposes. In Part III, we discuss our proposed alternative and explain why it is both workable and fair.

\section{SCIENTIFIC PROGRESS IS NOT ADEQUATELY PROMOTED UNDER EITHER THE ABSOLUTE BAR OR FLEXIBLE BAR}

The Patent Clause broadly directs that the Congress shall have the power to "promote the Progress of ... useful Arts, by securing for limited Times to ... Inventors the exclusive Right to their ... Discoveries." Crafting a statutory scheme to achieve this objective is the work of Congress, while enforcing that scheme in the manner that best comports with congressional intent and constitutional purpose is the obligation of the judiciary. ${ }^{12}$

To be effective, such a scheme must provide both effective protection for patentees and effective notice to the public. The flexible bar and the absolute bar each give one goal primacy over the other. Neither approach considers how innovation actually works. As a result, neither adequately fulfills the purposes embodied in both the Patent Clause and the Patent Act, which encourage both technological improvements and pioneering inventions through the careful balance of patents' protective and notice functions.

\section{A. Inventors Contribute to Progress through Both Pioneering Inventions and Technological Improvements}

The chief aim of the Patent Clause is to promote the public welfare by encouraging advancements in knowledge. ${ }^{13}$ Innovation generally takes one of two basic forms: pioneering inventions and technological improve-

11. U.S. ConST. art. I, $\S 8, \mathrm{cl} .8$.

12. Graham v. John Deere Co. of Kansas City, 383 U.S. 1, 5-6 (1966).

13. See Mazer v. Stein, 347 U.S. 201, 219 (1954) (noting that rewarding intellectual property owners encourages inventive efforts and hence is the "best way to advance public welfare"). 
ments of earlier inventions. Patent law must encourage both types of innovation, each of which is critical to the continued advancement of science and, thus, the public good.

A pioneering invention is something that performs a function never before performed-"a wholly novel device, or one of such novelty and importance as to mark a distinct step in the progress of the art ...,"14 By comparison, technological improvements are useful, though often minor, advances over the previously existing technology. However, even minor changes to prior art may be nonobvious before an invention is disclosed and may fundamentally change how an invention is used. The most useful and novel inventions may be merely progressive steps that in turn rely upon other inventions. ${ }^{15}$ This is particularly likely in certain industries, notably computer software, in which virtually all new products are developed by improving existing ones. ${ }^{16}$

Technological improvements may be the result of independent discoveries or intentional efforts to design around, and thereby avoid infringing, the claims of a patent. In either case, progress is served through innovation. Unlike copyists, who merely mimic a device and add nothing to the public body of knowledge, those who invent new devices by intentionally designing around a patent nonetheless advance the public welfare and fulfill the purpose of the Patent Clause. ${ }^{17}$

14. Westinghouse v. Boyden Power Brake Co., 170 U.S. 537, 562 (1898).

15. See HENRY PETROSKI, THE EVOlution OF USEFUl THINGS 45 (1992) (citing examples).

16. For a detailed discussion of how the cumulative nature of software innovation affects optimal doctrine of equivalents policy, see James Bessen \& Eric Maskin, Sequential Innovation, Patents, and Imitation (1999) (working paper, on file with authors); Julie E. Cohen \& Mark A. Lemley, Patent Scope and Innovation in the Software Industry, 89 CALIF. L. REV. 1 (2001). See also Mark A. Lemley \& David W. O'Brien, Encouraging Software Reuse, 49 STAN. L. REV. 255 (1997); Peter S. Menell, An Analysis of the Scope of Copyright Protection for Application Programs, 41 STAN. L. REV. 1045 (1989); Pamela Samuelson et al., A Manifesto Concerning the Legal Protection of Computer Programs, 94 COLUM. L. REV. 2308 (1994).

17. Warner-Jenkinson Co. v. Hilton Davis Chem. Co., 520 U.S. 17, 36 (1997) (contrasting "the intentional copyist making minor changes to lower the risk of legal action" with "the incremental innovator designing around the claims, yet seeking to capture as much as is permissible of the patented advance"); see also Slimfold Mfg. Co. v. Kinkead Indus., Inc., 932 F.2d 1453, 1457 (Fed. Cir. 1991) (Rich, J.) ("Designing around patents is, in fact, one of the ways in which the patent system works to the advantage of the public in promoting progress in the useful arts, its constitutional purpose."); State Indus. v. A.O. Smith Corp., 751 F.2d 1226, 1236 (Fed. Cir. 1985) ("One of the benefits of a patent system is its so-called 'negative incentive' to 'design around' a competitor's products, even when they are patented, thus bringing a steady flow of innovations to the marketplace."); Craig Allen Nard, A Theory of Claim Interpretation, 14 HARV. J.L. \& TECH. 1, 
40-41 (2000) ("The practice of designing-around extant patents creates viable substitutes and advances, resulting in competition among patented technologies. The public clearly benefits from such activity.") (citations omitted).

Closely related to the economic benefits of design-arounds are the economic benefits of reverse engineering. Most of the discussion on this topic has taken place in the context of software copyright, where courts and commentators overwhelmingly favor reverse engineering as a useful tool. E.g., Sony Computer Entm't, Inc. v. Connectix Corp., 203 F.3d 596 (9th Cir. 2000); Alcatel U.S.A., Inc. v. DGI Techs., Inc., 166 F.3d 772 (5th Cir. 1999); Bateman v. Mnemonics, Inc., 79 F.3d 1532, 1539 n.18 (11th Cir. 1996); DSC Communications Corp. v. DGI Techs., Inc., 81 F.3d 597, 601 (5th Cir. 1996); Lotus Dev. Corp. v. Borland Int'l, Inc., 49 F.3d 807, 817-18 (1st Cir. 1995) (Boudin, J., concurring); Atari Games Corp. v. Nintendo of Am. Inc., 975 F.2d 832, 84344 (Fed. Cir. 1992); Sega Enters. Ltd. v. Accolade, Inc., 977 F.2d 1510, 1527-28 (9th Cir. 1992); Vault Corp. v. Quaid Software Ltd., 847 F.2d 255, 270 (5th Cir. 1988); Mitel, Inc. v. Iqtel, Inc., 896 F. Supp. 1050 (D. Colo. 1995), aff'd on other grounds, 124 F.3d 1366 (10th Cir. 1997); JONATHAN BAND \& MASANOBU KATOH, INTERFACES ON TRIAL: INTELLECTUAL PROPERTY AND INTEROPERABIITY IN THE GLOBAL SOFTWARE INDUSTRY 167-226 (1995); Julie E. Cohen, Reverse Engineering and the Rise of Electronic Vigilantism: Intellectual Property Implications of "Lock-Out" Programs, 68 S. CAL. L. REV. 1091 (1995); Lawrence D. Graham \& Richard O. Zerbe, Jr., Economically Efficient Treatment of Computer Software: Reverse Engineering, Protection, and Disclosure, 22 RUTGERS COMPUTER \& TECH. L.J. 61 (1996); Dennis S. Karjala, Copyright Protection of Computer Software, Reverse Engineering, and Professor Miller, 19 U. DAYTON L. REV. 975, 1016-18 (1994); Maureen A. O'Rourke, Drawing the Boundary Between Copyright and Contract: Copyright Preemption of Software License Terms, 45 DUKE L.J. 479, 534 (1995); David A. Rice, Sega and Beyond: A Beacon for Fair Use Analysis . . At Least as Far As It Goes, 19 U. DAYTON L. REV. 1131, 1168 (1994); Pamela Samuelson, Fair Use for Computer Programs and Other Copyrightable Works in Digital Form: The Implications of Sony, Galoob and Sega, 1 J. INTELL. Prop. L. 49 (1993); Tyler G. Newby, Note, What's Fair Here is not Fair Everywhere: Does the American Fair Use Doctrine Violate International Copyright Law?, 51 STAN. L. REV. 1633, 1657-58 (1999); Timothy Teter, Note, Merger and the Machines: An Analysis of the Pro-Compatibility Trend in Computer Software Copyright Cases, 45 STAN. L. REV. 1061 (1993) (arguing that the value of computer programs depends on interoperability).

Some courts and commentators have argued against reverse engineering. E.g., Apple Computer, Inc. v. Franklin Computer Corp., 714 F.2d 1240 (3d Cir. 1983); Digital Communications Assocs., Inc. v. Softklone Distrib. Corp., 659 F. Supp. 449 (N.D. Ga. 1987); Anthony L. Clapes, Confessions of an Amicus Curiae: Technophobia, Law and Creativity in the Digital Arts, 19 U. DAYTON L. REV. 903 (1994) (contending that there should be no right to reverse engineer software); Arthur R. Miller, Copyright Protection for Computer Programs, Databases, and Computer-Generated Works: Is Anything New Since CONTU?, 106 HARV. L. REV. 977 (1993) (same). Cf. DSC Communications Corp. v. Pulse Communications, Inc., 170 F.3d 1354 (Fed. Cir. 1999) (acknowledging the right to reverse engineer for some purposes, but holding it unjustified in this case); Pamela Samuelson \& Suzanne Scotchmer, The Law and Economics of Reverse Engineering, YALE L.J. (forthcoming 2002). available at http://www.sims.berkeley.edu/ pam/papers/1\&e\%20reveng3.pdf (last visited Nov. 29, 2001) (suggesting that reverse engineering should be legal when it promotes interoperability but not when it permits free riding). 
Although pioneering inventions and technological improvements both rely to some extent on prior discoveries, ${ }^{18}$ they differ dramatically in their frequency. Pioneering inventions rely on unprecedented, breakthrough discoveries, which are uncommon. It is only the rare invention that strikes out in a sufficiently uncharted direction to qualify as a wholly novel device. Thus, in numerical terms, progress largely takes the form of technological improvements. ${ }^{19}$

Technological improvements may derive from either pioneering inventions or prior technological improvements. When a pioneering invention leads the way into a new art, technological improvements often follow in a flurry, as inventors seek to maximize the pioneering device's utility. It is this flurry of minor innovations that places technological improvements on par with their more revolutionary counterparts, though the social contribution of a single technological improvement may on occasion rival that of pioneering inventions. Generally, pioneering advances provide great leaps in society's collective progress, while technological improvements provide

In the patent context, there is some discussion of reverse engineering as well. The Supreme Court has noted its value as a font for innovation. See TrafFix Devices, Inc. v. Mktg. Displays, Inc., 121 S.Ct. 1255, 1260 (2001) ("IC]opying is not always discouraged or disfavored by the laws which preserve our competitive economy. Allowing competitors to copy will have salutary effects in many instances. 'Reverse engineering of chemical and mechanical articles in the public domain often leads to significant advances in technology."') (quoting Bonito Boats, Inc. v. Thunder Craft Boats, Inc., 489 U.S. 141, $160(1989)$ ). For arguments explicitly supporting the creation of a reverse engineering right in patent law, see Cohen \& Lemley, supra note 16, at 21-37, and Maureen A. O'Rourke, Toward a Doctrine of Fair Use in Patent Law, 100 COLUM. L. REV. 1177 (2000).

18. Ultimately, whether deemed pioneering inventions or technological improvements, all innovations build upon information already known to the public. All inventors have the fortune of standing on the shoulders of the proverbial giants who preceded them. See Sony Corp. of Am. v. Universal City Studios, Inc., 464 U.S. 417, 446 n.28, 477-78 (1984) (noting, in copyright case, that each person builds on the work of predecessors); Suzanne Scotchmer, Standing on the Shoulders of Giants: Cumulative Research and the Patent Law, 5 J. ECON. PERSP. 29 (1991). As Justice Story explained well over a century ago, "in literature, in science and in art, there are, and can be, few, if any, things, which, in an abstract sense, are strictly new and original throughout." Emerson v. Davies, $8 \mathrm{~F}$. Cas. 615, 619 (C.C.D. Mass. 1845). Cf. JAMES BoYle, ShamanS, SoFTware, AND SPLEENS (1996) (arguing that society systematically understates the extent to which creators borrow from preexisting works).

19. See In re Nelson, 280 F.2d 172, 182 (C.C.P.A. 1960) (Rich, J.) ("progress is made as the result of both the big and the little contributions, mostly the latter. We get ... a 'major scientific breakthrough'-only at rare intervals. The seemingly little advances are the bread and butter of progress and sometimes turn out to be of much greater importance than at first thought."). 
the multitudes of incremental steps necessary to realize the full potential of major as well as minor discoveries. ${ }^{20}$

\section{B. Patent Law Should Balance its Protective and Notice Functions and Thereby Promote Progress through Both Pioneering Inventions and Technological Improvements}

The law must encourage both pioneering inventions and technological improvements, to the exclusion of neither. This bedrock principle should guide the courts in interpreting the patent laws to promote the progress of the "useful Arts."

The difficulty is that the stronger the rights the law grants to pioneering inventors, the more difficult it becomes for others to improve on those pioneering inventions. Giving pioneering inventors total control over any work in the field puts them in the position of coordinating innovation. ${ }^{21}$ But there is powerful evidence that many diverse competitors, rather than one central decision-maker, are best situated to improve on an existing technology. ${ }^{22}$ As a result, economists and legal scholars generally suggest

20. See, e.g., RICHARD R. NELSON \& SIDNEY G. WINTER, AN EVOLUTIONARY THEORY OF ECONOMIC CHANGE 130 (1982); ANNALEE SAXENIAN, REgIONAL ADVANTAGE: CultuRE AND COMPETITION IN SILICON VAlley AND ROUTE 128 (1994); Nathan Rosenberg, Factors Affecting the Diffusion of Technology, 10 EXPLORATIONS IN ECON. HIST. 3 (1972); Carol Habor, Electronic Breakthroughs: Big Picture Eludes Many, Electronic News, Jun. 13, 1994, at 46 (detailing numerous examples of fundamental inventions that the inventor himself did not fully appreciate). Among the inventors who did not recognize the potential of their ideas are Marconi, who expected the radio to be used only for point-to-point communications rather than mass broadcast; the inventors of the transistor, who anticipated its use in hearing aids; and the inventors of the VCR, who anticipated it would only be used by television stations. Id. Relying only on pioneering inventors to commercialize their technologies may miss many useful improvements and applications, as it would have done in these cases.

21. The classic argument cited in favor of monopolists coordinating innovation is JOSEPH A. SCHUMPETER, CAPITALISM, SOCIALISM, AND DEMOCRACY 106 (1st ed. 1942). For an application to patent law, see F. Scott Kieff, Property Rights and Property Rules for Commercializing Inventions, 85 MINN. L. REV. 697 (2001); Edmund W. Kitch, The Nature and Function of the Patent System, 20 J.L. \& ECON. 265 (1977). Cf. Suzanne Scotchmer, Protecting Early Innovators: Should Second-Generation Products Be Patentable?, 27 RAND J. ECON. 322 (1996) (suggesting that incentives be weighted towards pioneers). The theory is that monopolists will have the resources to devote to research and development, and the fact that they can control all possible research in a field ex ante will encourage them to invent efficiently.

22. In the specific context of intellectual property, the canonical reply is Robert $\mathbf{P}$. Merges \& Richard R. Nelson, On the Complex Economics of Patent Scope, 90 ColuM. L. REV. 839 (1990). In the economic literature, see Kenneth J. Arrow, Economic Welfare and the Allocation of Resources for Invention, in THE RATE AND DIRECTION OF INVENTIVE ACTIVITY 609, 620 (Nat'l Bureau of Econ. Research ed., 1962), reprinted in 5 KEN- 
that the best way to encourage innovation is to balance the rights granted to pioneers and improvers, rather than allocate all rights to pioneers. ${ }^{23}$ This

Neth J. ARrow, Collected Papers of KEnNETh J. Arrow: Production and CaPITAL 104, 115 (1985). See also Morton I. KAMIEN \& NANCY L. SCHWARTZ, MARKeT STRUCTURE AND INNOVATION (1982); F.M. SCHERER \& DAVID ROSS, INDUSTRIAL MARKET STRUCTURE AND ECONOMIC PERFORMANCE 660 (3d ed. 1990) (criticizing Schumpeter's "less cautious" followers for advocating monopoly to promote innovation); Mark A. Lemley \& Lawrence Lessig, The End of End-to-End: Preserving the Architecture of the Internet in the Broadband Era, 48 UCLA L. REV. 925, 960-62 (2001) (arguing that the Internet was as innovative as it was because its architecture required competition rather than monopoly bottlenecks); Howard A. Shelanski, Competition and Innovation in U.S. Telecomm. 16-17 (Sept. 5, 2000) (unpublished manuscript, on file with authors) (finding that competition was a greater spur to innovation than monopoly in ten empirical studies in the telecommunications industry).

23. There are at least three strands to this argument. First, for a variety of reasons, society cannot rely on pioneers to efficiently license to improvers the right to compete with them. See Rebecca S. Eisenberg, Patents and the Progress of Science: Exclusive Rights and Experimental Use, 56 U. CHI. L. REV. 1017, 1072-73 (1989) ("The risk that the parties will be unable to agree on terms for a license is greatest when subsequent researchers want to use prior inventions to make further progress in the same field in competition with the patent holder, especially if the research threatens to render the patented invention technologically obsolete."); Mark A. Lemley, The Economics of Improvement in Intellectual Property Law, 75 TEX. L. REV. 989, 1048-72 (1997) (offering a variety of reasons why granting exclusive control to pioneers is inefficient); Robert P. Merges, Intellectual Property Rights and Bargaining Breakdown: The Case of Blocking Patents, 62 TENN. L. REV. 75 (1994) [hereinafter Merges, Intellectual Property]; Merges \& Nelson, supra note 22. Second, positive "spillovers" from innovation that cannot be appropriated by the innovator actually contribute to further innovation. See, e.g., Wesley M. Cohen \& David A. Levinthal, Innovation and Learning: The Two Faces of R\&D, 99 ECON. J. 569 (1989); Zvi Griliches, The Search for R\&D Spillovers, 94 SCAND. J. ECON. S29 (1992); Richard C. Levin, Appropriability, R\&D Spending, and Technological Performance, 78 AM. ECON. REV. 424, 427 (1988); Richard Schmalensee, $R$ and D Cooperation and Competition: Comments and Discussion, 1990 BROOKINGS PAPERS ON ECON. ACTIVITY 194, 195-96 (1990); Cf. Scotchmer, supra note 21 (noting difficulties in the optimal allocation of rights between pioneers and improvers). Third, granting strong intellectual property rights encourages rent-seeking, which may dissipate the social value of the property rights themselves. In the patent context, giving too strong a right to first inventors would encourage wasteful patent races. See, e.g., Jennifer F. Reinganum, The Timing of Innovation: Research, Development, and Diffusion, 1 HANDBOOK OF INDUS. ORG. 850 (Richard Schmalensee \& Robert Willig eds. 1989); Robert P. Merges, Rent Control in the Patent District: Observations on the Grady-Alexander Thesis, 78 VA. L. REV. 359 (1992). Cf. Mark F. Grady \& Jay I. Alexander, Patent Law and Rent Dissipation, 78 VA. L. REV. 305 (1992).

Of course, the operative word here is "balance." Pioneering inventors will emerge only if there are sufficient incentives for them to invent. Too great a division of rights can impede effective use of technologies. See Michael A. Heller \& Rebecca S. Eisenberg, Can Patents Deter Innovation? The Anticommons in Biomedical Research, 280 SCI. 698 (1998). The fact that the law must also encourage competition to improve 
is but one aspect of a larger theme in intellectual property law, which in all of its dimensions attempts to balance creators' rights to control their creations and society's right to use those creations. ${ }^{24}$ Patent law has a number of vehicles for achieving this balance. ${ }^{25}$

such pioneering inventions means that the law must take care to allocate rights between the parties. See Nard, supra note 17, 36-40.

For discussions of how to optimize that allocation, see, e.g., John H. Barton, Patents and Antitrust: A Rethinking in Light of Patent Breadth and Sequential Innovation, 65 ANTITRUST L.J. 449, 453 (1997), Howard F. Chang, Patent Scope, Antitrust Policy, and Cumulative Innovation, 26 RAND J. ECON. 34 (1995), and Jerry R. Green \& Suzanne Scotchmer, On the Division of Profit in Sequential Innovation, 26 RAND J. ECON. 20 (1995).

24. This effort at balance is a constant theme in Supreme Court intellectual property cases and the discussions of commentators. See, e.g., Graham v. John Deere Co. of Kansas City, 383 U.S. 1, 9 (1966) ("The patent monopoly was not designed to secure to the inventor his natural right in his discoveries. Rather, it was a reward, an inducement, to bring forth new knowledge."); Mazer v. Stein, 347 U.S. 201, 219 (1954) ("The economic philosophy behind the clause empowering Congress to grant patents and copyrights is the conviction that encouragement of individual effort by personal gain is the best way to advance public welfare ...."); see also Fogerty v. Fantasy, Inc., 510 U.S. 517, 524 (1994) ("The primary objective of the Copyright Act is to encourage the production of original literary, artistic, and musical expression for the good of the public."); Feist Publ'ns, Inc. v. Rural Tel. Serv. Co., 499 U.S. 340, 349-50 (1991) (stating that the "primary objective of copyright" is to promote public welfare); Stewart v. Abend, 495 U.S. 207, 224-25 (1990) (noting the Copyright Act's "balance between the artist's right to control the work ... and the public's need for access"); Bonito Boats, Inc. v. Thunder Craft Boats, Inc., 489 U.S. 141, 167 (1989) (noting the "careful balance between public right and private monopoly to promote certain creative activity"); Sony Corp. of Am. v. Universal City Studios, Inc., 464 U.S. 417, 429 (1984) (stating that the limited monopoly conferred by the Copyright Act "is intended to motivate creative activity of authors and inventors ... and to allow the public access to the products of their genius after the limited period of exclusive control has expired"); Twentieth Century Music Corp. v. Aiken, 422 U.S. 151, 156 (1975) (noting that "private motivation must ultimately serve the cause of promoting broad public availability of literature, music, and other arts"); Goldstein v. California, 412 U.S. 546, 559 (1973) (discussing Congress's ability to provide for the "free and unrestricted distribution of a writing" if required by the national interest); Fox Film Corp. v. Doyal, 286 U.S. 123, 127 (1932) ("The sole interest of the United States and the primary object in conferring the monopoly lie in the general benefits derived by the public from the labors of the authors.") (quoted in United States v. Paramount Pictures, 334 U.S. 131, 158 (1948)). For commentators' discussions, see, e.g., 1 PAUL GOLDSTEIN, COPYRIGHT $§ 1.14$, 1: 40 (2d ed. 1995); L. RAY PATTERSON \& STANLEY W. LINDBERG, THE NATURE OF COPYRIGHT 120-22 (1991); Cohen, supra note 13, at 1198; Karjala, Federal Preemption of Shrinkwrap and On-Line Licenses, 22 U. DAYTON L. REV. 511 (1997); Mark A. Lemley, Romantic Authorship and the Rhetoric of Property, 75 TEX. L. REv. 873 (1997); Pierre N. Leval \& Lewis Liman, Are Copyrights for Authors or Their Children?, 39 J. COPYRIGHT SOC'Y 1, 11 (1991); Jessica Litman, The Public Domain, 39 EMORY L.J. 965, 967- 68 (1990); Peter S. Menell, An Analysis of the Scope 
In the context of the doctrine of equivalents, the law best promotes progress by the careful balancing of dynamic protection for the patentee and clear notice to the public of what products will infringe the patent. Each of these patent functions is fundamental, and it is only by their harmonious interplay that patent law can encourage both technological improvements and pioneering inventions. ${ }^{26}$

The protective function of a patent-the constitutionally mandated right of its holder to exclude all others from practicing the invention for a limited time-is the principal feature of the patent system. ${ }^{27}$ In a market economy, the lure of obtaining a monopoly on a commercially profitable invention induces research, development, and, ultimately, progress in the form of new knowledge. ${ }^{28}$ The Patent Act offers this inducement by expressly prohibiting persons other than the patentee from making, using, or selling a patented device. ${ }^{29}$

The notice function of a patent requires inventors to provide a full and clear description of the invention, an enabling disclosure, and the "best mode" of carrying out the invention so that it may be made and used by any person skilled in the art. ${ }^{30}$ Patents thus inform the public of the precise nature of the protected subject matter, placing that knowledge in the public domain, subject only to the limited intrusion of the patentee's exclusivity right. ${ }^{31}$ Concomitantly, patents notify the public of what subject matter is not claimed, and therefore provide guideposts to subsequent improvers as

of Copyright Protection for Application Programs, 41 STAN. L. REV. 1045, 1082 (1989); Margaret Jane Radin, Property Evolving in Cyberspace, 15 J.L. \& COM. 509, 515 (1996). These are only a few of the innumerable citations on this point.

25. Thus, the broad rights conferred in 35 U.S.C. $\$ 271$ (1994); the ability to obtain a broadening reissue, 35 U.S.C. $\$ 251$ (1994); the pioneering patents rule, see John R. Thomas, The Question Concerning Patent Law and Pioneer Inventions, $10 \mathrm{HIGH}$ TECH. L.J. 35 (1995); and the doctrine of equivalents itself all serve to benefit pioneering inventors. The blocking patents rule, see Robert P. Merges, Intellectual Property supra note 23; the reverse doctrine of equivalents, see Westinghouse v. Boyden Power Brake Co., 170 U.S. 537, 562 (1898); Scripps Clinic \& Research Found. v. Genentech, Inc., 927 F.2d 1565 (Fed. Cir. 1991); the fact that patents expire after twenty years, 35 U.S.C. $\S 154$ (1994); and the ability to design around patents all serve to protect improvers.

26. See, e.g., Craig Allen Nard, Certainty, Fence-Building, and the Useful Arts, 74 IND. L.J. 759 (1999) (arguing that patent law must balance what the author calls "proprietary certainty"-our protective function-and "competitive certainty"-our notice function.).

27. Bloomer v. McQuewan, 55 U.S. (14 How.) 539, 549 (1852).

28. See Kewanee Oil Co. v. Bicron Corp., 416 U.S. 470, 480 (1974).

29. 35 U.S.C. § 271(a) (1994).

30. 35 U.S.C. $\$ 112$ (1994); Kewanee Oil Co., 416 U.S. at 480-81.

31. Bonito Boats, Inc. v. Thunder Craft Boats, Inc., 489 U.S. 141, 150-51 (1989). 
to what will and will not infringe. ${ }^{32}$ Thus, patent disclosure enriches the public domain through a useful description of the invention, and patent claims provide subsequent inventors with a description of the subject matter that lies within the exclusive possession of the patent holder.

The protective and notice functions of patents exist in some tension. The scope of the patent is defined by its claims. ${ }^{33}$ A competing inventor can avoid literal infringement by developing a new device that distinguishes the patented invention through slight modifications to avoid the language of the claims. Because the language of claims can never perfectly describe an invention or anticipate all the ways in which it might be modified, ${ }^{34}$ effective patent protection often requires claims to be read more broadly than their literal language would permit. Such a broad reading prevents insubstantial modifications from escaping a patent's scope of exclusivity. At the same time, however, the notice function requires claims to be read in a manner narrow enough to give meaningful effect to the limiting nature of the patentee's chosen language. These respective ends are achieved, or at least furthered, by two competing, judicially-created doctrines: the doctrine of equivalents and prosecution history estoppel.

First recognized by the Supreme Court in Winans v. Denmead, ${ }^{35}$ and expounded upon by the Court in Graver Tank \& Manufacturing Co. v. Linde Air Products Co. ${ }^{36}$ the doctrine of equivalents provides that a product or process that does not literally infringe on a patented device may be found to infringe if the accused device is deemed the equivalent of the patented device. The concept of equivalence protects a patent's value by enlarging the patent's scope to encompass devices whose variations from the patent's literal language are insubstantial. The Court recently reaffirmed the validity of the doctrine of equivalents in Warner-Jenkinson Co. v. Hilton Davis Chemical Co ${ }^{37}$ At the same time, the Court sought to cabin the doctrine's reach by limiting its application to each element of a claim, rather than to the invention as a whole. ${ }^{38}$ The Court also acknowl-

32. McClain v. Ortmayer, 141 U.S. 419, 424 (1891) ("The object of the patent law in requiring the patentee to [distinctly claim an invention] is not only to secure to him all to which he is entitled, but to apprise the public of what is still left open to them."); Hoganas AB v. Dresser Indus., 9 F.3d 948, 951 (Fed. Cir. 1993) (claims "put[] competitors on notice of the scope of the claimed invention.").

33. Markman v. Westview Instruments, Inc., 517 U.S. 370, 373 (1996).

34. See, e.g., Nard, supra note 17.

35. 56 U.S. $330(1853)$.

36. 339 U.S. 605 (1950).

37. 520 U.S. 17 (1997).

38. Id. at 29-30. The Federal Circuit had adopted this rule ten years earlier in Pennwalt Corp. v. Durand-Wayland, Inc., 833 F.2d 931 (Fed. Cir. 1987) (en banc). 
edged that the doctrine of equivalents, when applied broadly, conflicts with patents' notice function. ${ }^{39}$

Prosecution history estoppel limits the doctrine of equivalents by preventing a patentee from arguing equivalence with respect to subject matter the patentee surrendered during prosecution of the patent. ${ }^{40}$ The doctrine of prosecution history estoppel ensures that, to the extent possible, patents mean what they say. It prohibits patentees from obtaining a patent by representing to the PTO that the patent's scope is narrow, and then arguing otherwise to a court. Prosecution history estoppel is consistent with the notice function of patents because it allows third parties to rely on the public record of the patent prosecution to determine a patent's scope and eliminates the patentee's ability to rely on the doctrine of equivalents to expand that scope. ${ }^{41}$

Application of the doctrine of equivalents and prosecution history estoppel directly affects the incentives and disincentives to innovate. When the balance is tilted toward the protective function, patentees receive exclusivity beyond the literal language of their patents' claims, but improvers have less notice of an existing patent's scope. The resulting uncertainty discourages technological improvements because the outer margins of a patent's claims remain undefined, and the risk of infringing through a device that falls outside a patent's literal claims but within their substantial equivalents is not quantifiable. ${ }^{42}$

On the other hand, when the balance tilts too far toward the notice function, the reverse problem occurs. A patent's scope is so well defined in connection with the literal language of its claims that the patentee lacks protection from insubstantial modifications that amount to little more than a fraud on the patent. The incentive to advance knowledge only slightly, if

39. Id. at 29 ("There can be no denying that the doctrine of equivalents, when applied broadly, conflicts with the definitional and public-notice functions of the statutory claiming requirement.").

40. Id. at 30-31 (1997); Exhibit Supply Co. v. Ace Patents Corp., 315 U.S. 126, 13537 (1942).

41. Cf. White v. Dunbar, 119 U.S. 47, 51 (1886) (patent claims may not be treated "like a nose of wax which may be turned and twisted in any direction").

For a challenge to the idea that prosecution histories provide any effective public notice, see John R. Thomas, On Preparatory Texts and Proprietary Technologies: The Place of Prosecution Histories in Patent Claim Interpretation, 47 UCLA L. REV. 183, 200-04 (1999).

42. See Lemley, supra note 23 (warning that an overbroad doctrine of equivalents can stifle improvement); Merges \& Nelson, supra note 22 (same); $c f$. Nard, supra note 17 (arguing that patents must be interpreted with an eye towards defining their limits for the benefit of subsequent improvers). 
at all, becomes great, given the heightened certainty that modestly modified devices will not infringe. At the same time, the value of pioneering inventions, and the incentive to produce them, are substantially diminished by would-be inventors' concerns that their rights will be immediately diluted in the marketplace by competitors who have made, at best, insubstantial changes and, at worst, mere copies.

In sum, enforcing the doctrine of equivalents and prosecution history estoppel in a manner that balances patents' protective and notice functions is the optimal means of promoting the progress of the useful arts. Only through a careful balance of these functions will the law encourage innovation by both pioneering inventors and technological improvers.

\section{Neither the Absolute Bar nor the Flexible Bar Approach to Prosecution History Estoppel Achieves the Appropriate Balance}

The Federal Circuit in Festo substantially modified the law regarding the application of prosecution history estoppel. ${ }^{43}$ In doing so, the Federal Circuit overruled a series of its own cases, dating back to Hughes Aircraft Co. v. United States, ${ }^{44}$ which had established a flexible bar approach to prosecution history estoppel. The Supreme Court granted certiorari in Festo, and the case is pending at this writing.

The majority and dissents in Festo voiced divergent views regarding the appropriate scope of patent rights and the correct application of prosecution history estoppel, views now echoed by the parties and amici in the Supreme Court. Those supporting the decision argued that the pre-Festo rules for prosecution history estoppel under Hughes and its progeny effectively provided no notice to the public, creating broad patent protection unworkable in light of the realities of modern litigation practice. ${ }^{45}$ Those supporting the prior rule believe that the manner of applying prosecution history estoppel under Festo is even more problematic in light of the realities of modern invention and patent prosecution practice. ${ }^{46}$ Both sides have a point. Neither rule balances patents' protective and notice functions, and so each rule interferes with incentives to innovate. In the sections that follow, we explore these defects in detail.

43. Festo Corp. v. Shoketsu Kinzoku Kogyo Kabushiki Co., 234 F.3d 558 (Fed. Cir. 2000) (en banc), cert. granted, 121 S.Ct. 2519 (U.S. Jun. 18, 2001) (No. 00-1543).

44. 717 F.2d 1351 (Fed. Cir. 1983).

45. Festo, 234 F.3d at 575-78.

46. See, e.g., id. at 618-19 (Michel, J., concurring in part and dissenting in part). 


\section{Problems with the Flexible Bar}

The Federal Circuit in Hughes acknowledged that circuit court decisions predating the Federal Circuit's establishment took differing views on what range of equivalents, if any, would be available to a patentee where prosecution history estoppel applied. ${ }^{47}$ Hughes held that patentees who are estopped to assert infringement based on subject matter surrendered by amendment during prosecution may still claim some range of equivalents for that subject matter, with the available spectrum of equivalents ranging "from great to small to zero." 48

Hughes is emblematic of what came to be known as the flexible bar approach to prosecution history estoppel. Under this approach, the nature and purpose of amendments made during patent prosecution are examined to determine the exact subject matter that the patentee needed to surrender. Equivalents outside the surrendered material remain available to the patentee.

The flexible bar suffers from a fundamental lack of precision. Its essential quality - flexibility - has made it resistant to any clear formulation that would permit a competitor to predict as to exactly what subject matter has been surrendered by an amendment or a series of amendments during prosecution. Making this point in Festo, the Federal Circuit majority gave an example of a claim that originally recited a value of "less than twenty" and, in light of a rejection over prior art disclosing a value of fifteen, was amended to recite a value of "less than five." 49 There is no means by which an inventor wishing to use values of five and a half, ten or fourteen could ascertain whether the patentee surrendered those potential equivalents. The precise range of equivalents encompassed by the patent, and thus not available for practice by the public, will remain uncertain until litigation settles the matter.

Accordingly, the flexible bar defeats the notice function of patents by denying the public and would-be inventors reasonably clear notice of a patent's scope. This in turn threatens innovation. Indeed, incremental innovation in the form of technological advancements is particularly discouraged, since few inventors can be expected to take an unquantifiable risk of being sued for infringement. The flexible bar thus results in what the Supreme Court has previously referred to as a "zone of uncertainty which enterprise and experimentation may enter only at the risk of in-

47. Hughes Aircraft Co. v. United States, 717 F.2d 1351, 1362 (Fed. Cir. 1983).

48. Id. at 1363 .

49. 234 F.3d at 577. 
fringement claims ... [and which] discourage[s] invention only a little less than unequivocal foreclosure of the field." 50

There are other problems with the flexible bar approach as well. Most notably, by focusing on what the court ultimately decides is unpatentable, Hughes made the doctrine of prosecution history estoppel superfluous. It is well established in patent law that patentees cannot expand their claims under the doctrine of equivalents to cover inventions they could not have patented in the first place. For example, if an accused device would have been obvious in view of the prior art, the patent cannot cover that device, for doing so would mean that the patent itself was obvious. ${ }^{51}$ Thus, it adds little, if anything, to existing law for prosecution history estoppel to hold that an amended patent claim cannot be expanded to cover the prior art; that was already true without the doctrine of prosecution history estoppel. The flexible bar rule, then, not only gives insufficient notice to the public, but insufficient credence to the principle of estoppel. ${ }^{52}$ The estoppel doctrine should focus on whether the patentee's conduct during prosecution foreclosed some forms of protection, whether or not the patentee could legally have received that protection.

\section{Problems with the Absolute Bar}

In Festo, a majority of the Federal Circuit's judges determined that the problems associated with the flexible bar were too great for that rule to remain law. ${ }^{53}$ Festo instead adopted an "absolute bar" approach to prose-

50. Markman v. Westview Instruments, Inc., 517 U.S. 370, 390 (1996) (quoting Union Carbon Co. v. Binney \& Smith Co., 317 U.S. 228, 236 (1942)).

51. See, e.g., Streamfeeder, LLC. v. Sure-Feed Sys., Inc., 175 F.3d 974, 982 (Fed. Cir. 1999); Wilson Sporting Goods Co. v. David Geoffrey \& Assocs., 904 F.2d 677 (Fed. Cir. 1990); Loctite Corp. v. Ultraseal Ltd., 781 F.2d 861 (Fed. Cir. 1985).

52. See, e.g., Hughes Aircraft Co. v. United States, 140 F.3d 1470 (Fed. Cir. 1998); Litton Sys., Inc. v. Honeywell, Inc., 140 F.3d 1449 (Fed. Cir. 1998). Thus, the flexible bar approach is internally inconsistent, since the cases adopting that rule acknowledge that estoppel is appropriate, while applying estoppel only in circumstances in which the doctrine of equivalents would not apply even in the absence of estoppel. As a result, under the flexible bar the doctrine of estoppel is superfluous. See Prodyne Enters., Inc. v. Julie Pomerantz, Inc., 743 F.2d 1581, 1583 (Fed. Cir. 1984).

53. The Federal Circuit had issued a decision reaching a similar result shortly after Hughes was decided. Kinzenbaw v. Deere \& Co., 741 F.2d 383 (Fed. Cir. 1984). The decision in that case, however, made no mention of overruling Hughes, and the flexible bar of Hughes became the dominant line of Federal Circuit authority until Festo. Because it changed the prevailing law, Festo has been criticized for reducing the effective scope of existing patents and unfairly disrupting existing commercial relations. In his partial dissent, Judge Michel suggested that a "grandfathering" provision should be made for existing patents that contain amended claim limitations and were introduced before the 
cution history estoppel. Under this approach, no range of equivalents is available to a patentee with respect to any claim element to which prosecution history estoppel applies. Thus, where a limiting amendment to a claim triggers prosecution history estoppel, the patentee may pursue an infringement action only when the accused device infringes on the literal terms of that element of the patent's claims.

The absolute bar's purpose is to undo the chilling effect on innovation created by the flexible bar. The Federal Circuit's hope is that under the absolute bar, the undefined zone surrounding the literal terms of a narrowed claim will disappear, and technological advancements in this zone will no longer go undeveloped for fear of litigation. ${ }^{54}$ Additionally, newfound certainty regarding the scope of prosecution history estoppel should stimulate productive advances through improvements on and designs around patented technology.

Indisputably, the absolute bar promotes the notice function of patents. It is equally clear, however, that the absolute bar substantially compromises patents' protective function. The doctrine of equivalents is necessary to protect inventors from insubstantial modifications to patented devices that amount to little more than fraud on the patent. ${ }^{55}$ By denying patentees who amend their claims during prosecution the power to prevent infringement accomplished by minor variations from the amended language, the court jettisons a basic protection historically afforded patentees in favor of better informing the public of a patent's literal scope. ${ }^{56}$

This retooling of fundamental patent law concepts tips the balance between patents' protective and notice functions too far in the latter's favor. The PTO regularly rejects patent applications when they are initially filed. If those applicants are to succeed at all, they must either amend their claims to narrow them or argue that the claims are already narrow enough that amendment is unnecessary. To hold that one who amends a claim while successfully prosecuting a patent loses all protection against even minor variations on the narrowed claim effectively eviscerates the patent in many cases. This is particularly so because of the broad reading the

absolute bar could have been foreseen. Festo, 234 F.3d at 618-19 (Michel, J., concurring in part and dissenting in part).

54. Festo, 234 F.3d at 577.

55. See, e.g., Warner-Jenkinson Co. v. Hilton Davis Chem. Co., 520 U.S. 17 (1997); Graver Tank \& Mfg. Co. v. Linde Air Prods. Co., 339 U.S. 605 (1950); Winans v. Denmead, 56 U.S. (15 How.) 330 (1854).

56. See also Craig Allen Nard, Process Considerations in the Age of Markman and Mantras, 2001 U. ILL. L. REV. 355 (2001) (describing uniformity and certainty as having been elevated to the status of "mantras" by recent patent cases). 
Federal Circuit and other courts have given Festo in subsequent decisions. $^{57}$

Festo thus grossly disturbs the balance between patents' protective and notice functions and, as a result, distorts the patent system's incentives to innovate. The absolute bar encourages copyists to replicate a patented device, making otherwise meaningless modifications to the extent necessary to avoid the literal language of the device's amended claims. Judge Michel, in his partial dissent in Festo, declared this procedure to be a blueprint for lawful copying of patented material. ${ }^{58}$

The absolute bar also threatens to eliminate the incentive to produce socially valuable pioneering inventions. Any amendment to a pioneering invention's patent claims that relates to the device's patentability will prohibit the pioneering inventor from later using the doctrine of equivalents to protect her invention against an accused infringer. By their nature, however, pioneering inventions open whole new avenues of progress, and it is along such avenues that the opportunity to make insubstantial modifications from a patent's literal language is greatest. Denying pioneering inventors the benefits of the doctrine of equivalents may render wasted the investment expended to produce such inventions. This won't happen in all cases; patents are only one reason why inventors invent. ${ }^{59}$ But the absolute bar will reduce the incentives available from patents, which will reduce innovation to some extent.

Finally, under the absolute bar approach, all patented devices, whether pioneering inventions or technological improvements, are subject to lawful copying to the extent that after-invented technology allows a copyist to substitute a new technology for a claimed technology and thereby avoid a

57. See, e.g., Lockheed Martin Corp. v. Space Sys./Loral, Inc., 249 F.3d 1314, 1325 (Fed. Cir. 2001) (applying Festo bar to entire claim element, even though the claim element was only amended in one respect); Mycogen Plant Sci., Inc. v. Monsanto Co., 261 F.3d 1345 (Fed. Cir. 2001) (holding that Festo applies where limitation from dependent claim is included in independent claim); Pioneer Magnetics, Inc. v. Micro Linear Corp., 238 F.3d 1341, 1345 (Fed. Cir. 2001) (holding that inadvertent narrowing still triggers Festo bar); Brown \& Williamson Tobacco Corp. v. Philip Morris Inc., 229 F.3d 1120 (Fed. Cir. 2000) (holding Festo bar applies to multiple patents deriving from the same application); Control Res. Inc. v. Delta Elecs. Inc., 133 F. Supp. 2d 121 (D. Mass. 2001) (holding that claim amendment entirely bars doctrine of equivalents as to an element, even if the purpose of the amendment was to surrender only part of the range).

58. 234 F.3d at 616-17 (Michel, J., dissenting in part).

59. See, e.g., Wesley M. Cohen et al., Protecting Their Intellectual Assets: Appropriability Conditions and Why U.S. Manufacturing Firms Patent (or Not) (Nat'l Bureau of Econ. Research, Working Paper No. W7552, 2000); Richard C. Levin et al., Appropriating the Returns from Industrial Research and Development, 1987 BROOKINGS PAPERS ON ECON. ACTIVITY 783 (1987). 
patent claim's literal language. ${ }^{60}$ As Judge Rader pointed out in his partial dissent in Festo, this permits a patent's protection to be wholly defeated by the introduction of an item that functionally serves as an element of a narrowed claim but that does not come within the claim's literal language. ${ }^{61}$ The application of the Festo rule to later-developed technology is particularly disturbing, since in all likelihood the patentee had no intention of giving up ground that did not even exist at the time the amendment was made.

In sum, both the flexible bar and the absolute bar approaches to prosecution history estoppel fail to balance patents' protective and notice functions. To encourage both pioneering inventions and technological improvements, a middle ground is needed. We propose such an approach in the following section.

\section{THE FORESEEABILITY BAR: PROSECUTION HISTORY ESTOPPEL SHOULD BE APPLIED ONLY WHEN THE LIMITING EFFECT OF AN AMENDMENT WITH RESPECT TO AN ACCUSED DEVICE WOULD HAVE BEEN FORESEEABLE AT THE TIME OF THE AMENDMENT}

The concept of prosecution history estoppel is based on the equitable concept of an implied promise. The patentee is agreeing to narrow the scope of her claims in exchange for the grant of a patent, and should not be permitted to avoid that agreement by later claiming to own what she abandoned during prosecution. Sometimes the consequences of that implied promise are clear. ${ }^{62}$ In other cases, however, the patentee's "bargain" turns out to have unexpected consequences because of later-developed technologies or even unanticipated judicial interpretations of claim language. ${ }^{63}$ We think the equitable principle of estoppel and the economics of

60. Indeed, there is a well-developed body of patent law applying patents to cover later-developed technologies. See, e.g., Hughes Aircraft Co. v. United States, 717 F.2d 1351 (Fed. Cir. 1983); Laser Alignment, Inc. v. Woodruff \& Sons, Inc., 491 F.2d 866 (7th Cir. 1974); see also Texas Instruments, Inc. v. U.S. Int'l Trade Comm'n, 805 F.2d 1558 (Fed. Cir. 1986) (acknowledging the principle but finding no infringement in the case before it).

61. 234 F.3d at 619-20 (Rader, J., dissenting in part).

62. An obvious example is Warner-Jenkinson itself, where the addition of the claim language "at a pH from approximately 6.0 to 9.0 " made it quite clear what ground the patentee was giving up. 520 U.S. 17, 22 (1997).

63. Hughes may be an example of a case involving later-developed technology, since the accused device used technology (microprocessors installed on board a satellite) that did not exist at the time of the patented invention. See Hughes, 717 F.2d at 1351. 
innovation are both well served by distinguishing these cases. Doing so provides us with a rule that is neither "absolute" nor so "flexible" as to be meaningless: the doctrine of equivalents should be permitted to apply to amended claim language unless the limiting effect of the amended language with respect to an accused device would have been foreseeable at the time of the amendment.

Applied objectively, from the perspective of a reasonable person skilled in the art, this "foreseeable bar" applies principles that are readily, if not commonly, understood by both the public and the judiciary. Most importantly, the foreseeable bar rule provides both broader protection to the inventor than that provided by the absolute bar and more meaningful notice to the public than that provided by the flexible bar. The foreseeable bar thus better promotes innovation through pioneering inventions and technological improvements and, thereby, best promotes progress of the useful arts.

\section{A. The Foreseeable Bar Rule is Consistent with Patent Policies and Precedent in Other Areas}

Foreseeability is a well-understood and traditional jurisprudential device that courts employ to circumscribe legal principles in a manner that is flexible, and yet objective and reasonably determinate. For example, courts often use foreseeability to determine the existence of a common law duty of care in torts ${ }^{64}$ or as a measure to limit the scope of damages in civil contract actions. ${ }^{65}$ The Federal Circuit has also used foreseeability as a means to measure damages in patent infringement cases. ${ }^{66}$ Of more direct relevance to estoppel, the contract doctrine of promissory estoppel requires proof that a promisor should reasonably have foreseen that his promise would induce reliance by the person to whom the promise was made. ${ }^{67}$ Similarly, courts have used foreseeability to measure whether a

64. E.g., Palsgraf v. Long Island R.R., 162 N.E. 99 (N.Y. 1928) (Cardozo, J.); see, e.g., Peter F. Lake, Common Law Duty in Negligence Law, 34 SAN DIEGO L. REV. 1053 (1997) (contrasting elements of modern no-duty rules among the states). For discussions of the efficiency of the foreseeability rule in tort law, see ROBERT COOTER \& THOMAS UlEN, LAW AND ECONOMICS 367-69 (1st ed. 1988), A. Mrtchell POLINSKY, AN INTRODUCTION TO LAW AND ECONOMICS 39-51 (2d ed. 1989), Mark Grady, A New Positive Economic Theory of Negligence, 92 YALE L.J. 799 (1983), and Richard A. Posner, A Theory of Negligence, 1 J. LEGAL STUD. 29 (1972).

65. Hadley v. Baxendale, 156 Eng. Rep. 145 (1854) (holding that consequential damages in contract were appropriate).

66. Rite-Hite Corp. v. Kelley Co., 56 F.3d 1538 (Fed. Cir. 1995) (en banc).

67. RESTATEMENT (SECOND) OF CONTRACTS $\$ 90$ (1981). 
defendant's offensive use of collateral estoppel is fair. ${ }^{68}$ Thus, courts may draw upon long-established principles for guidance in determining whether a particular limiting effect of an amendment during patent prosecution was foreseeable at the time the patentee made the limitation.

The use of foreseeability is rooted in the case law of both the Supreme Court and the Federal Circuit. Foreseeability has already played a recognized role in effectuating patents' protective and notice functions in other patent doctrines. ${ }^{69}$ Indeed, a foreseeable bar approach may harmonize cases from both courts limiting application of the doctrine of equivalents by inquiring into what the patentee knew or should have known he was giving up. In Kinzenbaw v. Deere \& Co. ${ }^{70}$ the Federal Circuit relied on its prior decision in Hughes and the Supreme Court's decision in Graver Tank to conclude that the "doctrine of equivalents is designed to protect inventors from unscrupulous copyists ... and unanticipated equivalents." ${ }^{71}$ Thus, the Federal Circuit held, a patent applicant is not required to anticipate "all future developments which enable the practice of [each limitation of] his invention in substantially the same way."72 Turning to the facts before the court, Kinzenbaw found that the claimed variation was neither copied nor unanticipated, and the court held that prosecution history estoppel barred the patentee from relying on the doctrine of equivalents. ${ }^{73}$ Kinzenbaw plainly suggested that if the particular limiting effect created by the patentee's amendments to the patent's claim language had been unforeseeable, the doctrine of equivalents would still have been available to the patentee. ${ }^{74}$ Accordingly, Kinzenbaw relied squarely on foreseeability principles.

Sage Products, Inc. v. Devon Industries also took a foreseeability approach to the doctrine of equivalents, albeit outside the context of prosecution history estoppel. ${ }^{75}$ There, following the Supreme Court's command

68. Parklane Hosiery Co. v. Shore, 439 U.S. 322, 330 (1979) ("If a defendant in the first action is sued for small or nominal damages, he may have little incentive to defend vigorously, particularly if future suits are not foreseeable.").

69. Courts have, however, applied a test analogous to foreseeability: whether a competitor would be "reasonably entitled to conclude, from the prosecution history, that the applicant gave up" particular subject matter in order to obtain a patent. Haynes Int'l, Inc. v. Jessop Steel Co., 8 F.3d 1573, 1578, 1578 n.4 (Fed. Cir. 1993).

70. 741 F.2d 383 (Fed. Cir. 1984).

71. Id. at 389 (emphasis added).

72. Id. (quoting Hughes Aircraft Co. v. United States, 717 F.2d 1351, 1362 (Fed. Cir. 1983))

73. Id. at 389.

74. Kinzenbaw v. Deere \& Co., 741 F.2d 383 (Fed. Cir. 1984).

75. 126 F.3d 1420 (Fed. Cir. 1997). 
that "[t]he limits of a patent must be known,"76 the Federal Circuit held that, "as between the patentee who had a clear opportunity to negotiate broader claims but did not do so, and the public at large, it is the patentee who must bear the cost of its failure to seek protection for [a] foreseeable alteration of its claimed structure." ${ }^{.77}$ Sage Products specifically held that a patentee may not use the doctrine of equivalents to reach a foreseeable modification to a claimed innovation. ${ }^{78}$ The court observed that allowing the doctrine of equivalents to encompass foreseeable variations to claims would create a "zone of uncertainty, into which competitors tread only at their peril." $"$ A similar analysis may also provide a guiding principle for the controversial doctrine of dedication to the public domain, which is similarly based on competing conceptions of the protective and notice functions. ${ }^{80}$

A foreseeability approach is also consistent with the Supreme Court's prosecution history estoppel cases. In Exhibit Supply, ${ }^{81}$ the Court held that a patentee who selected limiting language to amend a claim while prosecuting the patent had thereby "recognized and emphasized the difference" between the original claim and the amended claim and thus "proclaimed his abandonment of all that is embraced in that difference." 82 The Court made no suggestion that the patentee's abandonment extended to equivalents that could not reasonably be foreseen. To the contrary, the Court's language suggested that the patentee specifically abandoned equivalents that should reasonably have been recognized when the patentee made the

76. Markman v. Westview Instruments, Inc., 517 U.S. 370, 390 (1996).

77. Sage Prods., Inc., 126 F.3d at 1425 (emphasis added).

78. Id. at 1425 .

79. Id. For an early discussion recognizing foreseeability as a new principle in patent law, see Andrew C. Greenberg \& Jeffrey R. Kuester, The "Palsgraffing" of Patent Law: Foreseeability and the Doctrine of Equivalents, INTELL. PROP. TODAY 17 (June 1998). See also Darius C. Gambino \& Richard A. Paikoff, A New Weapon for Alleged Infringers?: "Patent Drafter Estoppel" Explored, 10 FED. CIR. B.J. 469 (2001).

80. Subject matter that was disclosed in a patent but not claimed is deemed to have been affirmatively dedicated to the public. The rationale for this is that the patentee provided such information to the public without seeking claims to cover it, and the patentee should not be permitted to later withdraw the information from the public domain by use of the doctrine of equivalents or by reissue. See Miller v. Brass Co., 104 U.S. 350, 352 (1881) (applications for reissue). Compare Maxwell v. J. Baker, Inc., 86 F.3d 1098 (Fed. Cir. 1996) (holding that disclosed but unclaimed inventions are dedicated to the public domain) with YBM Magnex, Inc. v. Int'l Trade Comm'n, 145 F.3d 1317, 1322 (Fed. Cir. 1998) (rejecting doctrine of dedication to the public domain). The Federal Circuit recently agreed to resolve this conflict en banc. See Johnson \& Johnson Assocs. v. R.E. Serv. Co., 238 F.3d 1347 (Fed. Cir. 2001) (en banc).

81. Exhibit Supply Co. v. Ace Patents Corp., 315 U.S. 126 (1942).

82. Id. at 136-37. 
limiting amendment. ${ }^{83}$ Similarly, in Warner-Jenkinson, ${ }^{84}$ where the Court reaffirmed the application of the doctrine of prosecution history estoppel, the change the patentee made had obviously foreseeable effects, and the Court had no occasion to discuss the application of estoppel in the absence of foreseeability. ${ }^{85}$

In Festo, the Federal Circuit relied extensively on the need for foreseeability with respect to the scope of equivalents available to a patent's claims when the court held that limiting amendments based on patentability cannot be expanded beyond their literal language through the doctrine of equivalents. ${ }^{86}$ The en banc court emphasized that the flexible bar of Hughes made it "virtually impossible" to "predict[] with any degree of certainty the scope of surrender that will be found when prosecution history estoppel applies. ${ }^{87}$ But Festo relied only on the policy of foreseeability and did not inquire into the foreseeable effects of the specific amendments in the case before it. Indeed, the rule adopted in Festo will likely deter any such inquiry, since the court's analysis would bar any application of the doctrine of equivalents once the claim element has been amended, whether or not the patentee should have understood the effect of the amendment.

In sum, foreseeability is a well-established concept in modern law that is consistent with the basic patent functions of protection and notice. The concept also has antecedents in the doctrine of equivalents, as the Federal Circuit expressly used foreseeability for this purpose in Kinzenbaw and Sage Products, and the decisions in Hughes, Festo, and Exhibit Supply may reasonably be viewed as efforts to limit the doctrine of equivalents in accordance with basic principles of foreseeability. Accordingly, the use of foreseeability to limit application of the doctrine of equivalents is consistent with existing case law. ${ }^{88}$

83. Id.

84. Warner-Jenkinson Co. v. Hilton Davis Chem. Co., 520 U.S. 17 (1997).

85. The amendment added language "at a pH from approximately 6.0 to 9.0 ," which clearly excludes $\mathrm{pHs}$ well outside that range. $I d$. at 22 .

86. Festo Corp. v. Shoketsu Kinzoku Kogyo Kabushiki Co., 234 F.3d 558, 574-75 (Fed. Cir. 2000) (en banc), cert. granted, 121 S.Ct. 2519 (U.S. Jun. 18, 2001) (No. 001543).

87. Id. at 575.

88. In addition to the cases discussed above, a number of district courts have followed a foreseeability approach to the doctrine of equivalents. See, e.g., Knopik v. Amoco Corp., 96 F. Supp. 2d 892 (D. Minn. 2000); Kustom Signals, Inc. v. Applied Concepts, Inc., 52 F. Supp. 2d 1260 (D. Kan. 1999). 


\section{B. The Foreseeable Bar Rule Overcomes the Failings of the Absolute Bar and the Flexible Bar}

Under our proposed foreseeable bar, a court will apply the doctrine of equivalents notwithstanding a claim amendment unless the limiting effect of the amended language with respect to an accused device would have been foreseeable at the time of the amendment to a reasonable person skilled in the art. This foreseeable bar is not only fair, but also overcomes the considerable failings of both the flexible and the absolute bars, and thus best satisfies the fundamental constitutional policy of promoting the useful arts. The foreseeable bar avoids each parade of horribles posited by respective opponents of the flexible bar and the absolute bar, while at the same time advancing the aims of both groups.

To begin, application of the foreseeable bar is eminently fair. Where the limiting effect of an amendment with respect to an accused device should have been foreseen by a person reasonably skilled in the art, the law should not permit the patentee to ignore that effect by utilizing the doctrine of equivalents to expand a patent's claims to encompass subject matter that the patentee abandoned during prosecution. Instead, the patentee should be estopped from asserting equivalence. To do otherwise would at best reward bad claim drafting; at worst, it would give patentees perverse incentives to amend their claims freely to secure a patent and then make inconsistent arguments to the courts in infringement cases.

On the other hand, where the limiting effect of an amendment's language with respect to an accused device could not have been objectively foreseen at the time of the amendment - perhaps because the significance of the limitation was obfuscated by the "subtlety of language or complexity of the technology, [or a] subsequent change in the state of the art, such as later-developed technology" 89 -refusing to apply the doctrine of equivalents unfairly deprives the patentee of protection that the Supreme Court has repeatedly deemed essential to a meaningful right of exclusivity under the patent system. To impose a consequence on a patentee based ostensibly on the intent underlying the patentee's actions, but where those actions do not reasonably support any such intent, is the antithesis of fairness.

The foreseeable bar also overcomes the substantial failings of the absolute bar. As shown in Part II.C, supra, the absolute bar is unworkable and inimical to innovation because it permits competitors to use subject matter that effectively works a fraud on a patent. Wherever a patentabilitybased amendment is made to an element of a claim, the absolute bar en-

89. Sage Prods., Inc. v. Devon Indus., 126 F.3d 1420, 1425 (Fed. Cir. 1997). 
courages competitors to make trivial changes to avoid the patent, and the creation of pioneering innovations is correspondingly discouraged.

Under the foreseeable bar, these harsh consequences are largely avoided. The foreseeable bar prohibits use of the doctrine of equivalents only where the objective inference to be drawn from the patentee's acts shows that the equivalent subject matter in the infringing device was in fact abandoned during the patent's prosecution, thus opening the door to competitors' lawful use of that subject matter. The foreseeable bar does not discourage pioneering innovation, and it does not disproportionately encourage trivial changes, because the foreseeable bar permits the doctrine of equivalents to remain available to patentees even if a patent's claims are amended for reasons related to patentability. The only circumstance in which a patentee will be subject to estoppel is where it would be clear to a reasonable patentee that an amendment gives up particular ground.

Significantly, the foreseeable bar also permits ready and fair resolution of the effect of after-arising technology. In Festo, Judge Rader's dissent specifically criticized the absolute bar by noting that it permits competitors to "have unfettered license to appropriate all patented technology [that used] out-dated terms" in the face of subsequently developed technology. ${ }^{90}$ The foreseeable bar permits patent protection when insubstantial changes are made using after-invented technology that could not have been foreseen at the time of an amendment.

Further, the foreseeable bar permits patent protection where an accused infringer exploits subtleties of language or the inherent complexity of a technology to avoid the literal language of a patent's claims in a way that could not reasonably have been anticipated when the claim was amended. In those cases too, the foreseeable effect of the limiting language should govern. An example of such a case may be Lockheed Martin Corp. v. Space Systems/Loral, Inc. ${ }^{91}$ There, the original patent claim involved a method of orienting a satellite using a wheel whose rotation "varied sinusoidally" around an axis as the satellite deviated from an equatorial orbit. ${ }^{92}$ In response to prior art rejections, the claim was limited to sinusoidal variations with the same frequency as the orbital frequency of the

90. Festo Corp. v. Shoketsu Kinzoku Kogyo Kabushiki Co., 234 F.3d 558, 619 (Fed. Cir. 2000) (en banc), cert granted, 121 S.Ct. 2519 (U.S. Jun. 18, 2001) (No. 001543) (Rader, J., concurring in part and dissenting in part) (noting that the terms "cathode" and "anode" for vacuum-tube instruments gave way to "collectors" and "emitters" after the invention of the transistor).

91. 249 F.3d 1314 (Fed. Cir. 2001).

92. "Sinusoidal" means in the shape of a sine wave. 
satellite. ${ }^{93}$ The accused satellite did not literally infringe because the nature of the variation was not quite sinusoidal. ${ }^{94}$ The Federal Circuit held that the patentee could have no range of equivalents for the entire phrase, since the phrase had been changed to add the orbital frequency limitation. ${ }^{95}$ We think the result in this case would be different under the foreseeable bar. Lockheed could not reasonably have foreseen that an amendment related to orbital frequency would bar it from using the doctrine of equivalents to expand the definition of "sinusoidally," a term that was present in the original patent claim. Lockheed is an example of a case in which the patentee made an amendment intended to disclaim a totally different type of change than the one the defendant made. It seems inequitable to apply the absolute bar to such a case, as the court ultimately did. ${ }^{96}$

In his partial dissent in Festo, Judge Michel raised concerns that the absolute bar provided a blueprint for lawful copying of patented material. ${ }^{97}$ The foreseeable bar addresses this concern to the extent that the limiting effect of an amendment with respect to an accused device was not foreseeable. Where foreseeability is found, the patentee is deemed to have intended to abandon that particular equivalent, and thus neither patent law nor equity is offended by the competitor's use of the equivalent subject matter or by the application of prosecution history estoppel to the patentee.

Importantly, the foreseeable bar avoids not only the failings of the absolute bar but also the failings of the flexible bar. As discussed above, ${ }^{98}$ the flexible bar is problematic because the public cannot reasonably predict the outcome of its application in a particular case. As a result, the flexible bar discourages incremental innovations in the form of technological improvements. The foreseeable bar eliminates these concerns by eliminating the flexible bar's unbounded and broad-ranging inquiry, and replacing it with a straightforward and measurably more predictable foreseeability test.

Returning to the example used by the majority in Festo, where a claim for "less than twenty" is amended to "less than five" in view of prior art disclosing a value of fifteen, the reasonable person skilled in this particular art would readily foresee that equivalency to devices using a value over five was abandoned by the limiting amendment. An objective view of the meaning and effect of the patent language would permit a court to deter-

93. Lockheed Martin, 249 F.3d at 1326.

94. Id.

95. Id. at 1327.

96. Id.

97. 234 F.3d at 616-17 (Michel, J., concurring in part and dissenting in part).

98. See supra Part II.C. 
mine, as a matter of law, that prosecution history estoppel barred the patentee's infringement claim against an alleged infringer who used a value of five and a half.

Because the foreseeability test is objective-it asks what a reasonable person in the patentee's position would have understood an amendment's language to mean-it does not require proof of the inventor's state of mind. Rather, it draws on concepts with which patent courts are intimately familiar, like what the person having ordinary skill in the art would understand. Because the inquiry is objective and relates to the equitable principle of estoppel, it is just as amenable as the absolute bar to application by a court without the need for a jury trial. The test is necessarily factspecific, but no more so than many other patent doctrines. It may facilitate appellate courts acting as managers of the law rather than revisitors of fact. ${ }^{99}$ This is important, since one significant effect of Festo is to shift the power to decide many patent infringement cases from juries to judges. ${ }^{100}$ The foreseeable bar will not undo this shift.

By comparison, as the Festo majority complained, the flexible bar calls for a pliable examination of a series of extraneous factors. Under the flexible bar of Hughes, to determine the scope of equivalents remaining after the amendment, a judge must not only consider claim construction, but also the panoply of issues relating to a study of prosecution history, validity in view of the prior art cited and of record, and the totality of the circumstances under which the patentee amended the application. The judge must then formulate that scope of equivalents and then either apply it to the accused device or relate it to a jury through an instruction that, like the claims themselves, may be constrained by the limitations of language in conveying the inventive idea. On appeal, the reviewing court must revisit all of the factors considered below and may well view their totality differently than the trial judge. As a result, in each case the ultimate resolution of the estoppel question will remain uncertain until the appeal is concluded.

Under the flexible bar, an inventor wishing to improve a device through a technological innovation that was arguably an equivalent to the

99. See William C. Rooklidge \& Mathew F. Weil, Judicial Hyperactivity: The Federal Circuit's Discomfort with its Appellate Role, 15 BERKELEY TECH. L.J. 725 (2000) (arguing that the Federal Circuit is insufficiently deferential to district court factfinding). Cf. Mark D. Janis, Patent Law in the Age of the Invisible Supreme Court, 2001 U. ILL. L. REV. 387, 408-09 (2001) (suggesting such a role for the Supreme Court in patent cases).

100. This shift in turn is part of a broader trend in patent law towards greater decision-making by judges. See, e.g., Markman v. Westview Instruments, Inc., 517 U.S. 370 (1996); Cybor Corp. v. FAS Techs., Inc., 138 F.3d 1448 (Fed. Cir. 1998) (en banc). 
amendment's literal language cannot predict whether a court will apply prosecution history estoppel to the patentee or permit a jury trial on equivalence. Lawful innovations may never reach fruition because the uncertainty of the existing patent's scope presents too great a litigation risk. This result is inconsistent with promoting progress, and is unnecessary in light of the more predictable foreseeable bar alternative.

Thus, while the foreseeable bar is not a bright-line rule like the absolute bar, it provides a concise test that is both flexible and readily comprehensible to both the public and the courts. The foreseeable bar is therefore more consistent than the flexible bar with the Supreme Court's mandate that prosecution history estoppel be an "objective" inquiry. ${ }^{101}$ The foreseeable bar asks the trial judge only whether the limiting effect of an amendment as applied to exclude an accused device from literal infringement was foreseeable at the time of the amendment. Unlike the flexible bar, the foreseeable bar is more focused, restricting the inquiry to a particular limiting effect of particular claim language with respect to a particular accused device. The bases for the trial judge's conclusion can be readily articulated in an opinion, which in turn can be reviewed as a matter of law by an appellate court.

Ultimately, the foreseeable bar is more equitable than the absolute bar and more certain than the flexible bar. Thus, as a matter of policy, the foreseeable bar presents the best means of promoting progress of the useful arts.

Of course, there will be disputes in particular cases about whether the limiting effect of a particular amendment should have been foreseeable. However, the foreseeable bar is amenable to case-by-case development by the courts to ensure equity and compliance with the purposes of the patent system. In sharp contrast, the bright-line rule of Festo all but forecloses the opportunity for further refinement where its results prove unjust. Similarly, despite twenty years of case-by-case development, the flexible bar has remained sufficiently unmoored to firm principles that it has never overcome its unpredictable and inequitable nature. Thus, unlike the absolute and flexible bars, a foreseeable bar would facilitate the capacity of district courts to "best ... implement procedural improvements to promote certainty, consistency, and reviewability to this area of the law."102

101. Warner-Jenkinson Co. v. Hilton Davis Chem. Co., 520 U.S. 17, 36 (1997).

102. Id. at 39 n. 8 . 


\section{CONCLUSION}

The courts should interpret the Patent Act to promote the innovation and dissemination of new technologies to the public benefit. With respect to prosecution history estoppel, both the absolute bar and the flexible bar fail to meet this interpretive goal. Unlike the absolute and flexible bars, the proposed foreseeable bar is easily grasped and applied, assures both equity and predictability, and is consistent with patent law policies and case law. It is the best alternative available to the courts to harmonize the conflicting, but critical, policies of protection and notice, and it best promotes both pioneering inventions and technological improvements. 